\title{
Laser Technology for Caries Removal
}

\author{
Adriana Bona Matos, Cynthia Soares de Azevedo, \\ Patrícia Aparecida da Ana, Sergio Brossi Botta and Denise Maria Zezell \\ University of São Paulo, School of Dentistry and Nuclear and Energetic Research Institute, \\ Brazil
}

\section{Introduction}

Laser technology has been in the scope of dentistry community since Stern \& Sognnaes (1964) studied laser application on dental hard tissues. Lasers have become an attractive instrument for many dental procedures including soft tissues surgery (Sperandio et al., 2011), decontamination (Benedicenti et al., 2008; Koba et al., 1998) and for assuring antiinflammatory effects (Lang-Bicuto et al., 2008). In restorative dentistry, laser has been used successfully for cavity preparation (De Moor et al., 2010; Obeidi et al., 2009), caries prevention (Namoour et al., 2011; Rechmann et al., 2011; Zezell et al., 2009), caries decontamination (Namour et al., 2011) and caries removal (Neves et al., 2011; White et al., 1993). For that, high intensity lasers are indicated, which are able to promote controlled temperature rise in a small and specific area of dental hard tissue (Ana et al., 2007). Depending on the temperature rise and the interaction of laser irradiation with dental tissues, it is possible to produce specific micro structural and/or mechanical changes related to a correct clinical application.

The use of lasers for cavity preparation and caries removal is based on the ablation mechanism, in which dental hard tissue can be removed by thermal and/or mechanical effect during laser irradiation (Seka et al., 1996). This mechanism relies on the type of tissue to be irradiated, as well as the characteristics of laser equipments. The knowledge of laser wavelength, laser emission, pulse duration, pulse energy, repetition rate, beam spot size, delivery method, laser beam characteristics (Ana et al., 2006), and optical properties of the tissue, such as the refractive index, the scattering coefficient $\left(\mu_{s}\right)$, the absorption coefficient $\left(\mu_{\mathrm{a}}\right)$, and the scattering anisotropy (Featherstone, 2000a) are necessary to assure better clinical results without thermal or mechanical damages to the dental hard tissue.

For irradiation in dental hard tissues, the most frequent laser systems used are Nd:YAG $\lambda=$ $1.064 \mu \mathrm{m})$, Argon $(\lambda=0.488 \mu \mathrm{m})$, Ho:YLF $(\lambda=2.065 \mu \mathrm{m})$, Ho:YAG $(\lambda=2.100 \mu \mathrm{m})$, Er:YAG $(\lambda$ $=2.940 \mu \mathrm{m})$, Er,Cr:YSGG $(\lambda=2.780 \mu \mathrm{m})$, Diode $(\lambda=0.810 \mu \mathrm{m})$ and $\mathrm{CO}_{2}(\lambda=9.300 \mu \mathrm{m}$ or $9.600 \mu \mathrm{m}$ or $10.600 \mu \mathrm{m})$. With the exception of the argon laser, these lasers emit in infrared range of electromagnetic spectrum, and a good number of equipment operates at the free running mode, with pulse durations of microseconds $(\mu \mathrm{s})$. Considering that laser wavelength must be absorbed by enamel and dentin to assure the efficient caries removal and cavity preparation (Seka et al., 1996), the most successful laser systems for this purpose 
are erbium and $\mathrm{CO}_{2}(\lambda=9.6 \mu \mathrm{m})$ lasers. However, the $\mathrm{CO}_{2}(\lambda=9.6 \mu \mathrm{m})$ systems are not commercially available for applications in dentistry.

Considering the advances in technology for the development of ultra short pulse lasers (USPLs) (Niemz, 1995; Strickland \& Mourou, 1985), efforts have been implemented to understand their interaction with dental hard tissues and to determine safe and proper parameters to provide a future clinical application in dentistry (Altshuler et al., 1994; Freitas et al., 2010; Kruger et al., 1999; Lizarelli et al., 2008; Strassl et al., 2008). Due to the extremely short pulse length, these systems promote precise cutting and have a strong potential for obtaining well-defined cavities and controlled caries removal (Niemz, 2004; Serbin et al., 2002). Also, due to the use of low energies per pulse, it is possible to adjust parameters bellow the ablation threshold for sound tissue which, at the same time, can ablate and remove the carious tissue (Niemz, 2004; Strassl et al., 2008). In this way, the selective removal of carious tissue could be seen as a minimal intervention that does not depend on the professional experience, but essentially relies on the tissue chemistry (Serbin et al., 2002).

The operation of laser systems and interactions with dental hard tissues, the clinical diagnosis and the knowledge of the characteristics of the tissue to be irradiated are extremely important to assure a well-succeeded therapy. Professionals must evaluate the mineralization degree and chemical composition of the tissue to be removed, the extension and localization of caries, the activity degree of lesions and the interference of the irradiation on the restorative procedure.

In this chapter, focus will be given on the last developments concerning the use of highintensity lasers in restorative dentistry, describing the different laser wavelengths, the mechanisms of interaction with dental hard tissue and the influence of pulse width on removing these tissues. Also, the effects of laser irradiation on carious tissues will be described, and the possibility of removing dental caries with laser irradiation will be discussed to help dentists to choose a suitable equipment and technique for improving their clinical practice.

\section{Laser interaction with dental hard tissues}

Depending on laser wavelength and tissue characteristics, laser irradiation can be absorbed, scattered, reflected or transmitted into dental tissues (Ana et al., 2006; Featherstone, 2000; Niemz, 2004; Seka et al., 1996). These effects must be well known by professionals to help them choose the best equipment for a specific clinical application and to avoid thermal and mechanical damages to the target and surrounding tissues. Depending on the clinical situation, dentists need different laser wavelengths and irradiation parameters to obtain distinct effects on the same tissue.

Considering the applications in restorative dentistry, the conventional high-intensity infrared lasers can be well-suited for caries removal (Neves et al., 2010; Tachibana et al., 2008; White et al., 1993), cavity preparation (De Moor \& Delme, 2010; Moldes et al., 2009; Obeidi et al., 2009;) and tissue conditioning (Botta et al., 2009; Dundar \& Gunzel, 2011). For that, continuous emission lasers or pulsed laser longer than 1 picosecond should be well absorbed by the main components of teeth, i.e., water and hydroxyapatite; to promote the desired thermal and mechanical effects on these tissues, in a process called thermal ablation 
due to a thermomechanical effect (Fried, 2000; Niemz, 1995; Seka et al., 1996). For shorter pulses, such as femtosecond laser pulses, the ablation occurs due to non-linear interactions with the tissue resulting in a plasma-mediated ablation.

The thermal ablation process that occurs in dental hard tissues is also known as explosive (water-mediated) tissue removal (Fried, 2000; Niemz, 1995; Seka et al., 1996). In a few words, this process can be explained as a result of the fast heating of the subsurface water confined by the hard tissue matrix, due to the higher interaction with infrared laser irradiation. The heating of these water molecules leads to an increase on molecular vibration and, consequently, an increase on subsurface pressures that can exceed the strength of the above tissue. Finally, it can be noted an "explosion" of tissue due to the material failure, resulting in the material removal. This process happens in temperatures below the melting point of dental hard tissues (around $1200^{\circ} \mathrm{C}$ ) and varies according to the laser wavelength (e.g., Er:YAG reaches $300^{\circ} \mathrm{C}$ at the ablation threshold, while Er,Cr:YSGG reaches $800^{\circ} \mathrm{C}$ and $\mathrm{CO}_{2}$ $9.6 \mu \mathrm{m}$ reaches $\left.1000^{\circ} \mathrm{C}\right)$ ((Seka et al., 1996; Fried et al., 1996). This process has been studied for the past 30 years, with the intention of choosing the best laser wavelength and parameter to effectively promote tissue removal or selective caries removal with minimal thermal consequences (Stern \& Sognnaes, 1964; White et al., 1993; Neves et al., 2010; Ana et al., 2007; Seka et al., 1996; Tachibana et al., 2008; Moldes et al., 2009; Botta et al., 2009; Dundar \& Gunzel, 2011).

For understanding how laser irradiation can provide a more conservative treatment of caries lesions, the chemical composition of target tissue must be known by the professional. Human enamel is composed by $95 \%$ hydroxyapatite $\left(\mathrm{Ca}_{10}\left(\mathrm{PO}_{4}\right)_{6}\left(\mathrm{OH}_{2}\right)\right)$, $4 \%$ water and $1 \%$ collagen fibers (Gwinnett, 1992); as well as human dentine contains 70\% hydroxyapatite, $20 \%$ collagen fibers and 10\% water (Ziip \& Bosch, 1993). Considering the differences in composition and the higher resonance of $\operatorname{Er:YAG~}(\lambda=2.94 \mu \mathrm{m})$ by water $(\lambda=3 \mu \mathrm{m})$, we can infer that Er:YAG laser can ablate dentin faster than enamel. The same rule is valid when comparing carious tissue with sound ones, taking into account that decayed tissues have a significant higher amount of water. In this way, in a clinical application, professionals can observe easier caries removal when compared to the removal of sound surrounding tissues, and this fact can influence the laser irradiation parameters that should be used for different application.

Dental enamel and dentin have a weak absorption in the visible $(400-700 \mathrm{~nm})$ and nearinfrared (1064 nm) wavelength ranges; however, absorption bands of water and carbonated hydroxyapatite is found from 2.7 to $11 \mu \mathrm{m}$ (Figure 1) (Ana et al., 2006; Fried 2000). The optical penetration of Nd:YAG on enamel is significantly high, indicating that the dentin irradiation with $\mathrm{Nd}$ :YAG laser can affect the pulp tissue in case of high energy densities, long exposure or in the absence of a photoabsorber (Boari et al., 2009). However, Nd:YAG laser can be indicated for removal of stained caries tissue, promoting a selective removal of caries lesion without pulpal damages due to the higher interaction of Nd:YAG by pigments (Seka et al., 1996), as it was demonstrated by a clinical trial performed by White et al. (1993).

Considering the use of Er,Cr:YSGG laser, literature evidences (Stock et al., 1997) that the 2.78 $\mu \mathrm{m}$ is strongly absorbed by the dental hard tissue since the optical absorption coefficient of enamel is about $7000 \mathrm{~cm}^{-1}$. In this way, the optical penetration is a few micrometers smaller than the obtained by Er:YAG laser. 


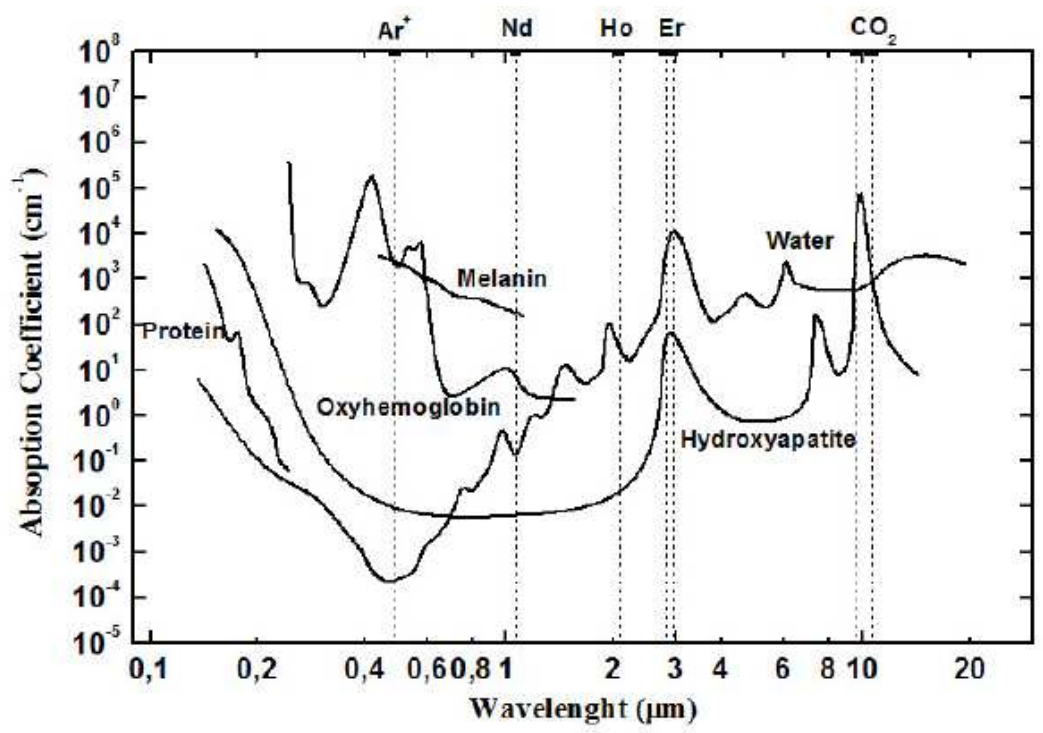

Fig. 1. Absorption coefficients for the main chromophores of biological tissues (Ana et al., 2006).

Since the approval of erbium lasers for dental hard tissues use by FDA in 90's, Er:YAG and Er,Cr:YSGG have been extensively studied for caries therapy. The literature present a number of advantages over the high-speed drills for the removal of caries, such as reduction of pain, noise, vibration (Fried, 2000; Niemz, 2004; Seka et al., 1996; White et al., 1993), the possibility of selective removal (Eberhard et al., 2005; Neves et al., 2010) and the changes in chemical composition of remaining tissue (Ana et al., 2006; Bachmann et al., 2009; Botta et al., 2011), leading to a tissue that is resistant to demineralization. That is why erbium lasers can be considered a clinical reality in dental offices.

\section{The use of erbium lasers for caries therapy}

The erbium lasers are solid-state lasers produced with different types of matrix crystals. Some of them, such as Er:YAG $(\lambda=2.94 \mu \mathrm{m}), \operatorname{Er}$,Cr:YSGG $(\lambda=2.78 \mu \mathrm{m}), \operatorname{Er}: Y L F(\lambda=2.81$ $\mu \mathrm{m})$, Er:YAG $(\lambda=2.73 \mu \mathrm{m})$ and CTE:YAG $(\lambda=2.69 \mu \mathrm{m})$, were already studied for ablation of dental hard tissues (Altshuler et al., 1994). From all of them, the most popular and with commercially available equipments for dentistry are Er:YAG and Er,Cr:YSGG.

Comparing the absorption of Er:YAG with Er,Cr:YSGG lasers by dental hard tissues, it is possible to observe that Er:YAG have a strong interaction with $\mathrm{OH}^{-}$from water molecules contained in the teeth, while Er,Cr:YSGG is better absorbed by water and $\mathrm{OH}^{-}$contents of hydroxyapatite (Figure 2)(Ana et al., 2006). Due to this fact, Er:YAG promotes surface temperatures up to $300^{\circ} \mathrm{C}$ at the ablation threshold, and Er,Cr:YSGG reaches $800^{\circ} \mathrm{C}$ during ablation of enamel (Fried et al., 1996).

Although it have been tested some erbium lasers operating in the Q-switched mode (with pulse duration in the range of ns) (Fried, 2000), the commercially available erbium lasers 
operate in free running mode, with pulse duration of $150-400 \mu \mathrm{s}$. This pulse duration is shorter than the thermal relaxation time of dental hard tissues (<1ms) (Niemz, 2004), which provide heat dissipation during ablation and avoid excessive heat transmission to the pulp, for instance. However, at higher energy per pulses, erbium lasers can induce thermal injuries to dental hard tissue, such as the presence of microcracks, melting or even carbonization. In this way, during the clinical application, it is essential to use the correct set up of laser parameters and the use of an adequate air-water spray to provide proper refrigeration and avoid these side effects. However, although the presence of a thin layer of water can increase the ablation process (Fried at al., 2002), an excessive water layer can decrease erbium interaction with dental hard tissues (Niemz, 2004); in this way, the use of saliva suction is recommended.

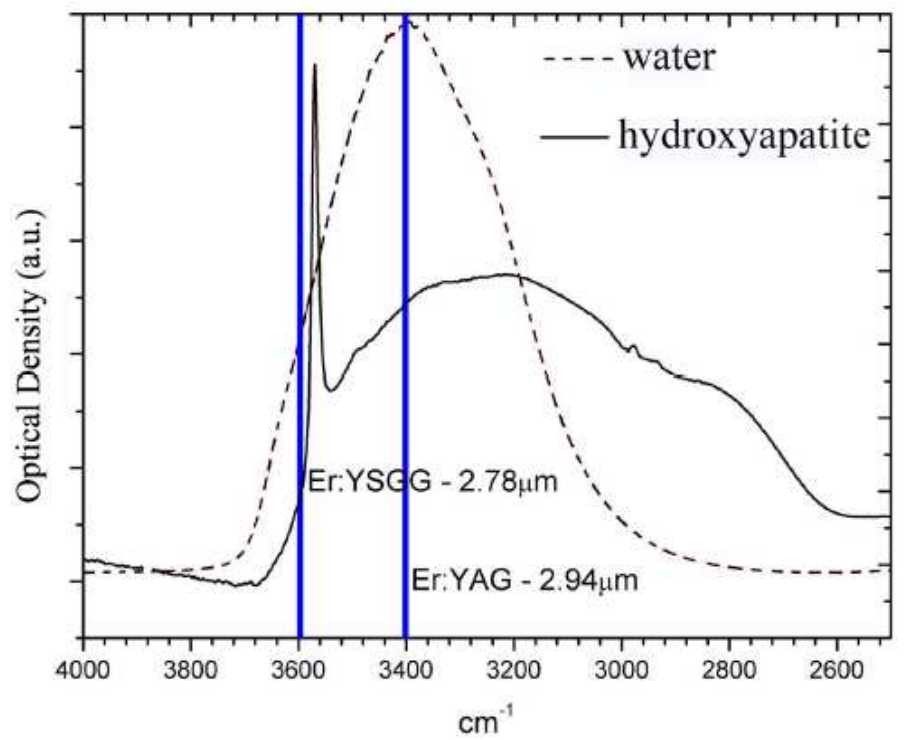

Fig. 2. Absorbance of water and hydroxyapatite and their relation with Er:YAG and Er,Cr:YSGG lasers (Ana et al., 2006).

Er:YAG lasers became popular for using in dental hard tissues at the end of 1980s, when researchers tested the Er:YAG for ablation of enamel, dentin and caries lesions on extracted teeth (Hibst \& Keller, 1989). Since then, several studies have been performed to determine parameters and conditions for a safe and efficient application in daily practice for soft and hard tissue applications (Altshuler et al., 1994; De Moor \& Delme, 2010; Eberhard et al., 2005; Fried et al., 1996, 2002; Hibst \& Keller, 1989; Moldes et al., 2009; Neves et al., 2010; Stock et al., 1997; White et al., 1994). On the other hand, the popularity of Er,Cr:YSGG laser started later, since the first studies tested the possibility of ablation of dental hard tissues on early 90's. In vitro (Altshuler et al., 1994; Ana et al., 2007; Bachmann et al., 2009; Botta et al., 2011; Dundar \& Guzel, 2011; Fried et al., 1996; Moldes et al., 2009; Obeidi et al., 2009; Stock et al., 1997; Tachibana et al., 2008) and in vivo (Yazici et al., 2010; Yilmaz et al., 2011) studies confirmed the feasibility of this wavelength for several applications on dental hard tissues, such as cavity preparation and caries removal. 
During cavity preparation, the ablation of sound enamel by Er:YAG laser promotes cavities with rough enamel margins, with irregular and rugged walls, with depth that depends on the energy density and pulse width (Navarro et al., 2010). As well, it is reported the absence of smear layer, cracks, carbonization or melting if the adequate parameters and refrigeration were used (Botta et al., 2009). As Er:YAG, the enamel cavities produced by Er,Cr:YSGG laser irradiation present their floor with fissures and conical craters with sharp enamel projections and, in some areas, with the exposition of the enamel rods. The roughness of cavities is also dependent on the energy densities used (Ana et al., 2007; Olivi et al., 2010; Tachibana et al., 2008).

In sound dentin, due to the differences in composition and morphology, erbium lasers promote a higher removal of peritubular than the intertubular dentin. In this way, both Er:YAG and Er,Cr:YSGG promote the formation of rough surfaces with opened dentinal tubules, absence of smear layer, cracks or melting, with protrusion of peritubular dentin due to its less amount of water when compared to the intertubular dentin (Botta et al., 2009, 2011). The irregularities promoted by laser irradiation vary according to the energy density applied. Considering these facts, the differences in temperature rises at the ablation threshold promoted by Er:YAG and Er,Cr:YSGG seem to be unable to induce significant distinct morphological effects during cavity preparation.

In contrast, the use of high-speed drills for cavity preparation promotes enamel and dentin cavities flattened, with smooth internal walls and geometrically well-defined shapes, with closed dentinal tubules and presence of smear layer (Botta et al., 2009; Navarro et al., 2010). These characteristics, as well as the changes in chemical and crystalline structure in remaining tissue promoted by laser irradiation, must be taken into consideration in order to choose an appropriate adhesive system for composite restoration, since the adhesive systems interact in a different way with laser or bur treated tissues (Moretto et al., 2011).

Erbium lasers are also effective on removal of dental caries. In vitro studies revealed that Er:YAG and Er,Cr:YSGG can selectively remove dental caries due to the higher amount of water and organic content when compared to sound tissues (Eberhard et al., 2008; Tachibana et al., 2008); in this way, it is possible to obtain a conservative therapy, with no removal of sound tissue and lack of thermal damages. However, the adjustment of laser energy density in commercial equipments is sometimes difficult to promote the selective ablation of infected dentin and in order to preserve the affected dentin, and the clinical results still depend on the experience and knowledge of the professional, added to the use of manual instruments for correct diagnosis of remaining tissue. In fact, clinical trials report the well acceptance of patients (Dommisch et al., 2008; Krause et al., 2008), the maintenance of pulp vitality and marginal seal, the good quality of restorations and the absence of secondary caries even after two years (Yazici et al., 2010). Also, it is reported that these lasers can fulfill the requirements of Minimal Invasive Dentistry, due to the possibility of conservation of the sound tissue structure during caries removal and to the possibility of surface decontamination of affected dentin (Kornblit et al., 2008).

To determine an end point for caries removal, there are some equipments that associate Er:YAG laser irradiation to the diagnosis by laser fluorescence (Dommisch et al., 2008; Eberhard et al., 2008; Jepsen et al., 2008; Krause et al., 2008;). The essential principle of this application is that the fluorescence of sound tissue differs from the fluorescence of carious 
tissue due to the variation in chemical composition, such as the presence of proteins, bacteria and other contents. In this equipment, the fluorescence is induced by red laser that emits at the wavelength of $655 \mathrm{~nm}$, and the Er:YAG laser is turned off when significant changes on fluorescence are detected during caries removal, established by a cut-off value that indicates that all decayed tissue was removed. Some in vitro (Eberhard et al., 2008; Jepsen et al., 2008) and in vivo (Dommisch et al., 2008; Krause et al., 2008) studies showed the feasibility of this equipment; however, there is no consensus about the correct values of cutoff in different clinical conditions. Also, it must be emphasized that there are limitations of this technique mainly in dentin (Eberhard et al., 2008; Krause et al., 2008), when falsepositive can be reported due to the presence of pigments in affected or tertiary dentin, for instance, which should not be removed. In this way, the association of manual instruments and is still necessary to assure a safe and correct clinical removal of dental caries.

Clinical trials have demonstrated that Er:YAG and Er,Cr:YSGG lasers can be considered a safe and efficient treatment for caries removal, since it is reported pulpal response and histological effects similar to those obtained by the use of conventional bur. Also, due to the lack of noise, pressure, discomfort and sometimes the necessity of local anesthesia, it is reported a good compliance of patients, mainly the pediatric ones. However, it must be emphasized that the time necessary to remove caries by laser irradiation is almost two or three times longer than the bur treatment, depending on the repetition rate and energy density (Navarro et al., 2010; Yamada et al., 2001). The increase of energy density and repetition rate can lead to discomfort and pain to patients, besides increasing the surface temperatures. For this reason the strategies used for improving the laser ablation speed are limited (Navarro et al., 2010).

\section{Influence of pulse width on tissue removal}

Although the pulse duration of most commercial lasers (range of $\mu \mathrm{s}$ ) is shorter than the thermal relaxation time of dental hard tissues, laser ablation promotes irregular cavities (depending on composition of target tissue), desiccation of the surface (due to the removal of underlying water) and the presence of few microcracks (related to the energy density), the amount of water coolant and the repetition rate must be adjusted during the clinical procedure.

The adjustment of repetition rate is important to assure that the inter-pulse period is longer than the thermal relaxation time of tissues; in this way, it is possible that the temperature of the irradiated tissues decrease between laser pulses (McDonald et al., 2001). Another strategy for cooling the tissue during laser irradiation is reducing the pulse duration (Seka et al., 1995). Depending on the pulse duration ( $<1 \mathrm{ps})$, the process of ablation is changed and the non-linear processes (or non-thermal ones) take place (Ana et al., 2006; Freitas et al., 2010; Kruger et al., 2008; McDonald et al., 2001; Niemz, 2004; Strassl et al., 2008).

According to Niemz (1995), lasers with pulse durations in the range of ms $\left(10^{-3} \mathrm{~s}\right), \mu \mathrm{s}\left(10^{-6} \mathrm{~s}\right)$ or ns (10-9 s) generate considerable heat during ablation of dental hard tissues, in a mechanism mediated by thermal interaction. On the other hand, lasers with pulse durations of ps $\left(10^{-12} \mathrm{~s}\right)$ and fs $\left(10^{-15} \mathrm{~s}\right)$ ablate the tissues by forming an ionizing plasma. These lasers, commonly called as USPL (ultra short pulse lasers), operates at very high repetition rate (larger than $15 \mathrm{kHz}$ ) and energy per pulse typically of hundreds of $\mu \mathrm{J}$ (Wieger et al., 2006). 
Although USPLs have extremely higher repetition rate ( $>\mathrm{KHz}$ ) and peak power (up to TW), previous studies relate that a single ultra short laser pulse removes significantly less volume of dental tissue when compared to conventional Er:YAG laser removal (Strassl et al., 2008). This fact occurs due to the differences in focal size and penetration depth of USPLs (which are severely lower when compared to Er:YAG lasers that operate at pulse width of $\mu \mathrm{s}$ ); in this way, the pulse repetition rate had to be increased in USPLs to obtain a similar ablation volume than those obtained by Er:YAG (Wieger et al., 2006).

Some literature studies compared the morphological aspects, as well the depth of craters during ablation of dental hard tissues with lasers operating with distinct pulse widths. Niemz (1995) relates that the Nd:YLF laser $(\lambda=1053 \mathrm{~nm})$ operating with pulse duration of 30 ps provide cavity preparation on sound and decayed enamel without severe thermal or mechanical damages, with negligible shock-wave effects. Also, in the same paper, they showed that the ablation of carious enamel was 10 times more efficient than the ablation of sound enamel. A study performed by McDonald et al. (2001) showed that the total deposited energy on tissue as well the laser pulse duration change the crater depth generated on dentin, and the Nd:YAG with pulse width of 35 ps is unable to promote carbonization of dentin in comparison with a Nd:YAG laser with pulse width of ms.

The heating of dental hard tissues can induce composition and crystallographic changes on these tissues which are dependent on temperature rises. In this way, both morphological aspects and chemical analysis are indicative of thermal effects of lasers on enamel and dentin. A study performed by Kamata et al. (2004) showed that the chemical properties of hydroxyapatite (HAp) are unchanged after ablation with lasers operating with pulse widths of $50 \mathrm{fs}, 500 \mathrm{fs}$ and 2 ps. These results suggest that USPLs do not significantly increase the temperature of HAp. On the other hand, the use of Nd:YAG operating with pulse duration of $6 \mathrm{~ns}$ and $200 \mathrm{~ns}$ on enamel promote melting and recrystallization of this tissue (Antunes et al., 2005), indicating temperature rises up to $1200^{\circ} \mathrm{C}$. Also, with the pulse duration of $6 \mathrm{~ns}, \mathrm{Nd}$ :YAG promoted changes on organic content of enamel and dentin (Antunes et al., 2006).

Thermal measurements were performed using a laser with pulse width of fs on enamel using thermocouples, and it was detected temperature rises about $2^{\circ} \mathrm{C}$ on enamel surfaces after a $8 \mathrm{~ms}$ train of $70 \mathrm{fs}$ pulses (Pike et al., 2007). This fact indicates that the USPLs do not induce significant thermal rises on surfaces and on surrounding tissues and can be used with safety even without refrigeration.

\section{The use of Ultra Short Pulse Lasers (USPLs) in dentistry}

Even with the higher repetition rates and the application of air-water coolant during the cutting process, commercially high intensity infrared lasers still cannot cut dental hard tissues with the same speed or the same precision than those promoted by drills (White et al., 1994). In this way, studies were performed to verify the possibility of using ultra short pulse lasers (USPLs) for cutting dental hard tissues, considering the success of using the USPL for precise cutting in industry and in medicine (ophthalmology) (Niemz, 2004).

The USPLs were first developed to allow spectroscopic and electrical conductivity measurements (Strickland \& Mourou, 1985) and, according to Strassl et al. (2008), studies 
concerning the use of USPLs for medical applications started more than 15 years ago. In fact, one of the first studies that report the use of lasers with pulse widths of ps and fs was performed by Stern et al. (1989), relating applications for corneal ablation. Since then, efforts were made to understand the effects of these lasers on biological tissues and to develop of practically applicable systems. Although the majority of the studies report the use of laboratorial equipments for biological purposes, nowadays it is possible to find commercially available equipments for ophthalmology and for laboratorial use; this fact indicates that, in a near future, commercial equipments can be available for dentistry applications too.

The USPLs are lasers with pulse duration ranging from 100 fs to 500 ps, with power densities above $10^{11} \mathrm{~W} / \mathrm{cm}^{2}$ in solids (Niemz, 2004). The main characteristics of these complex systems (Freitas et al., 2010) are the very low pulse duration and the high precision that can be acquired due to the extremely small focalization area, in which a peak power up to 1.5 TW (Freitas et al., 2010) can be obtained. Also, these lasers can operate at repetition rates higher than $15 \mathrm{kHz}$ and energy per pulse of hundreds of $\mu \mathrm{J}$ (Wieger et al., 2006). In this way, these lasers offer the advantage of promoting precise smooth ablation without a heataffected zone, effects that cannot be controlled when using lasers with pulse duration of $\mu$ s or ns. Some researchers report that the main advantage of using the USPLs in dentistry is to achieve a controlled material removal and, as a consequence, reducing the pain caused by the vibration and friction heat (Kruger et al., 1999). According to Neev et al. (1996), the main advantages of USPLs are: the decreased energy density to ablate the material; minimal mechanical and thermal damages due to the extremely short laser pulses; minimal dependence of the tissue composition for ablation; precision in the ablation depth; low noise level in comparison with high-speed bur; ability to texture surface and precise spatial control.

The USPLs are solid-state lasers, such as $\mathrm{Nd}: \mathrm{YLF}, \mathrm{Ti}: \mathrm{Al}_{2} \mathrm{O}_{3}, \mathrm{Cr}: \mathrm{LiSAF}$ (Alexandrite), $\mathrm{Cr}: \mathrm{BeAl}_{2} \mathrm{O}_{4}, \mathrm{Cr}: \mathrm{LiSGaF}, \mathrm{Cn}: \mathrm{LiCAF}, \mathrm{Cr}: \mathrm{YAG}_{1} \mathrm{Ti}: \mathrm{Al}_{2} \mathrm{O}_{3} / \mathrm{Nd}$ :glass, Er:glass. These lasers interact with the tissues by a mechanism called plasma-induced ablation or plasma mediated ablation, in which the phenomenon of optical breakdown occurs. In a few words, the ablation is caused by plasma ionization, in which laser irradiation produces an extremely high electric field that forces the ionization of the molecules and atoms, promoting a breakdown and, then, the ablation or ejection of target tissue (Niemz, 2004). During the cutting, it is possible to observe the formation of a bright plasma spark, and a typical low noise, characteristic of plasma formation.

Considering the strictly short pulse durations and the low energy per pulse in USPLs systems, it is possible to infer that the ablation process is practically not dependent on the wavelength or the composition and absorption characteristics of the tissue (Perry et al., 1999). Also, the removal of ablated material is faster than the heat propagation on the tissue, i.e., the pulse length is lower than the heat conduction time of target tissue (Perry et al., 1999); in this way, there is no transmission of heat to pulp or surrounding tissues, for example, as well, no thermal damages to the irradiated tissues. Other advantage of using USPLs in dentistry is that these systems can remove any kind of restorative material, including amalgam (Freitas et al., 2010), which is not possible using other systems due to the reflection of light or overheating of the material. 
Although they are characterized by extremely high peak powers, the USPLs uses lower energy densities when compared to laser with pulse width of $\mu \mathrm{s}$. The reduction of the energy density is because the femtosecond laser energy densities necessary for micromachining are an order of magnitude lower than those in the nanosecond-laser case for equal wavelength and repetition rate (Kruger et al., 1999).

The ablation of dental hard tissues with USPLs were investigated by Niemz et al. (1995), using a system with pulse length of 30 ps. These authors reported enamel cavities with good precision and absence of thermal damages when compared with cavities performed by lasers operating with pulse length of $\mu \mathrm{s}$ and ns. Further researches confirmed that the application of USPLs with pulse length of few femtoseconds almost completely avoids thermal damages and the formation of microcracks on irradiated tissues and on surrounding ones (Kruger et al., 1999; Freitas et al., 2010). It must be pointed out that lasers that operate with pulse length of $\mu$ s can generate the formation of microcracks on irradiated tissue depending on the energy density, and these thermal damages can be responsible for the development of secondary caries (Apel et al., 2005).

Other studies were performed to verify the feasibility of removing restorative materials with USPLs, since these lasers can ablate any kind of material. Also, the literature reports the selectivity on removing different materials due to the different nature of interaction of USPLs with dielectric or metal materials, for instance (Freitas et al., 2010). In this way, it is easier to adjust a laser fluence that can be bellow or above the ablation threshold of a specific material. Literature studies determined that the threshold fluence for ablating enamel with USPL is higher than the fluence for ablating dentin and, in the same way that using erbium lasers, it is easier and faster to ablate dentin than enamel, which suggests selectivity to the tissue removal (Lizarelli et al., 2008; Niemz et al., 2004; Strassl et al., 2008; Wieger et al., 2006;). In 2006, Wieger et al. used a picosecond $\mathrm{Nd}: \mathrm{YVO}_{4}$ laser for ablation of sound dentin, and it was observed the production of a microretentive pattern with opened tubules and the absence of microcracks or melting. These authors also compared the ablation rate (i.e. the ablation volume per laser pulse) of seven types of composite resins, and showed that the ablation rates of restorative materials are much higher than that measured on dentin, demonstrating that the removal of restorative materials is faster than dental hard tissue. Another study performed by Freitas et al. (2010) determined the ablation threshold fluence for removal of amalgam and composite resin restorations by a femtosecond chirped Ti:sapphire laser. In this work it was also demonstrated the selectivity of USPLs in the material removal process suggesting a selective preparation, preserving health tooth structure.

Concerning the removal of dental caries, literature studies reported that the threshold fluence for carious dentin is lower than that for sound dentin, also suggesting a selective removal of caries (Niemz, 2004). A recent study (Schelle et al., 2011) that used a Nd:YAG laser with 8 ps pulse duration confirm that the ablation threshold for carious dentin is lower than that for sound dentin and it was obtained good precision even when removing caries. These findings suggest that the USPLs are promising tools for selective removal of dental caries; however, the literature is scarce considering the applications of USPLs for selective removal of dental caries in order to establish suitable equipments and parameters. Also, there are no studies that relate the possibility of selective removal of infected dentin and preserving the affected dentin, for instance. 
Although it is reported the possibility of precise removal of tissue with USPLs, it should be pointed out that the time required for a cavity preparation with USPLs is higher than the time required when using a laser with pulse duration of $\mu$ s or a drill, even with the higher repetition rate of the available systems (Kruger et al., 1999). Although there is some commercially available equipment for ophthalmology, the application of USPLs in dentistry for cavity preparation and caries removal is not yet a routine technique, and the cost and complexity of systems still represent a problem to be solved.

\section{Adhesion to caries affected dentine}

Carious lesions have different characteristics depending on diverse factors such as host, diet, period of time and injury severity. Controversial results can be observed in the literature of adhesion to caries-affected dentine. While some studies claim that the bond strength obtained in caries affected dentine is similar to the attained in sound tissue (Mobarak et al., 2010; Zanchi et al., 2011; Zawaideh et al., 2011), other researchers detected lower bond strength when adhesives were applied on caries affected dentine (Kunawarote et al., 2011; Marquesan et al., 2009; Perdigão, 2010). Basically, these diverse results can be due to the use of natural carious human molars to compose the sample. Although some studies use artificial caries affected dentine (Zanchi et al., 2011) results are still controversial. Also, using natural carious substrate in experimental studies can induce results with high variability; consequently, they do not allow direct comparison between studies.

Bonding to standard artificially obtained caries affected laser irradiated dentine could not be detected in literature. The following figures present the differences observed in caries affected dentin irradiated by distinct types of lasers. Also, a comparison between these surfaces and the sound ones is essential, because adhesive systems were developed to interact with smear layer covered dentine.

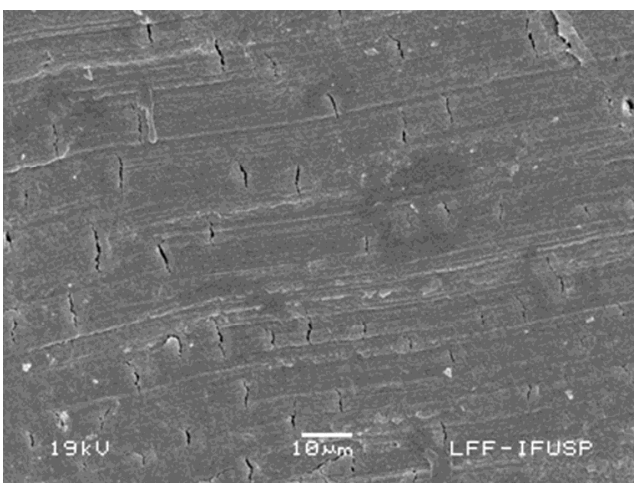

A

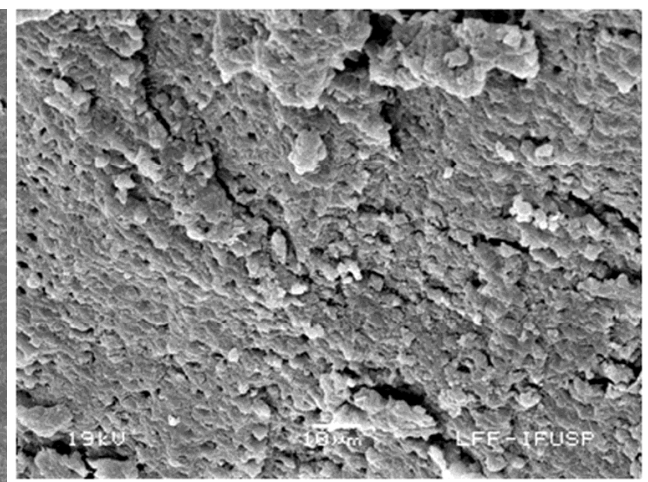

B

Fig. 3. Scanning electron micrographs of sound (A ) and carious (B) human dentine. ATypical smear layer image, with clear indication of tubules apertures position by the presence of microcracks, suggesting a thin smear layer; B - Presence of biofilm on dentine surface, areas with exposed open tubules, while other regions are considered free of debris. Original magnification: $A=1000$ X; B $=500$ X. 


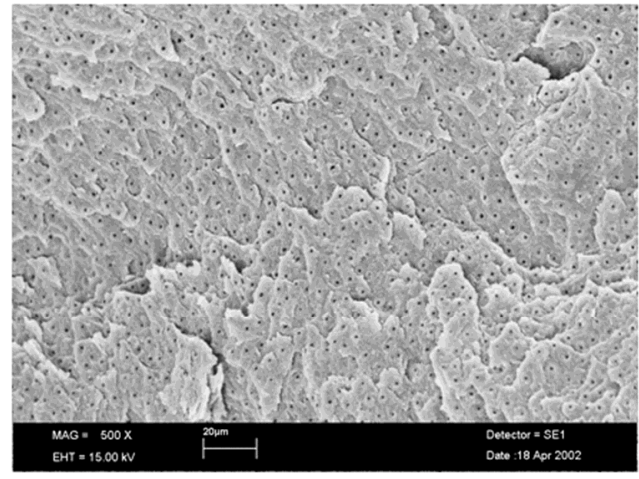

A

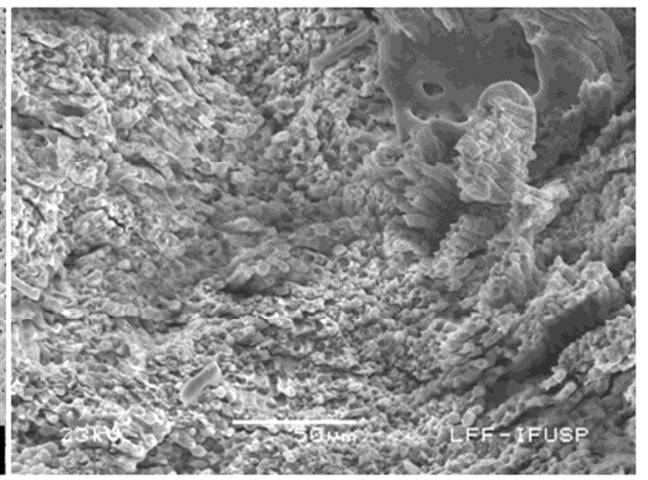

B

Fig. 4. Scanning electron micrographs of sound (A) and carious (B) human dentin after irradiation with Er:YAG laser $(\lambda=2940 \mathrm{~nm}$, pulse width of $400 \mu \mathrm{s}$, beam diameter of $1 \mathrm{~mm}$, repetition rate of $10 \mathrm{~Hz}$ ). A - sound dentin. Typical Er:YAG laser ablation where we can see open dentinal tubules in a irregular dentinal surface ; B - when carious dentin is irradiated the surface is absolutely irregular, completely covered by debris and biofilm, indicating that carious tissue remains on the surface. Original magnification: $500 \mathrm{X}$.

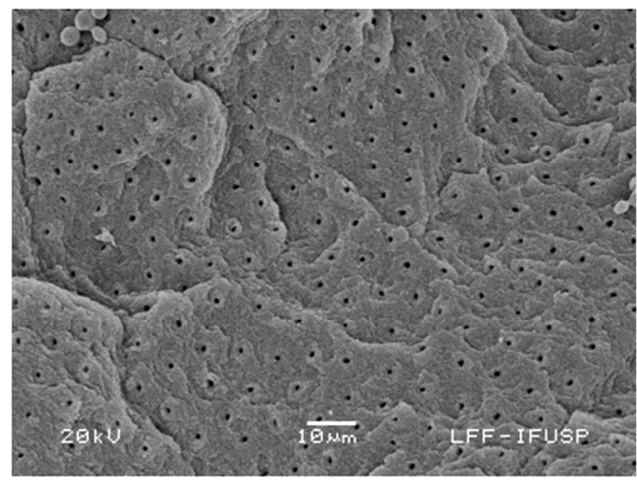

A

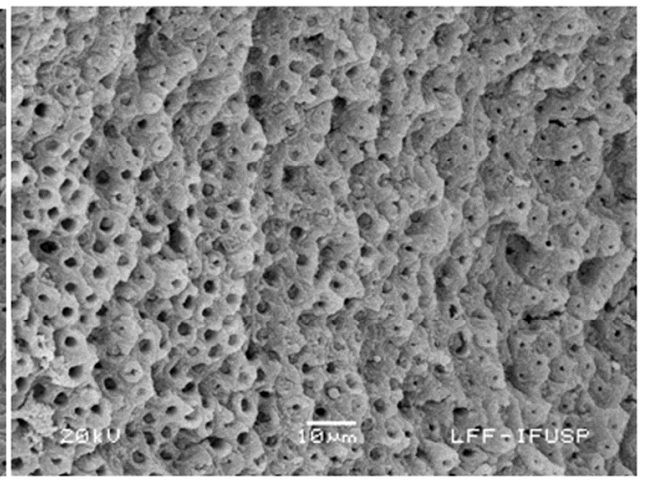

B

Fig. 5. Scanning electron micrographs of sound (A) and carious (B) human dentin after irradiation with a Er,Cr:YSGG laser $(\lambda=2078 \mathrm{~nm}$, pulsed width of $140 \mu \mathrm{s}$, repetition rate of $20 \mathrm{~Hz}$, beam diameter of $750 \mu \mathrm{m})$. A - As sound dentin is irradiated by Er,Cr:YSGG laser an irregular dentinal surface is created by the ablation process. Dentinal tubules are open and peritubular dentine can be easily detected around all dentinal tubules; B - Carious irradiated dentin still presents open dentinal tubules, but are larger in diameter and filled with debris from the carious tissue. Note that these features are completely distinct from the irradiation by Er:YAG laser. Original magnification: $1000 \mathrm{X}$. 


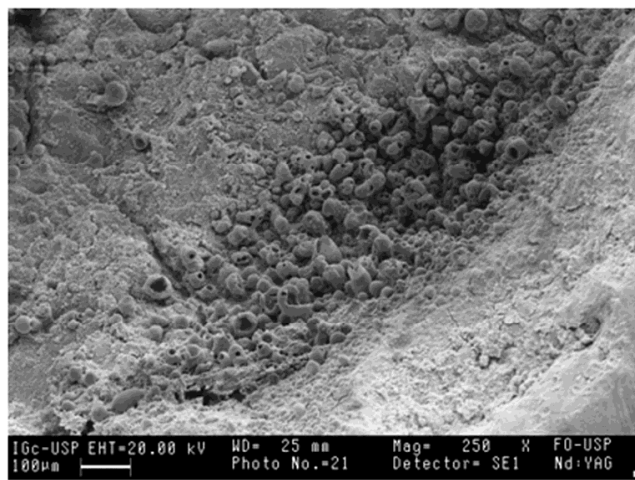

A

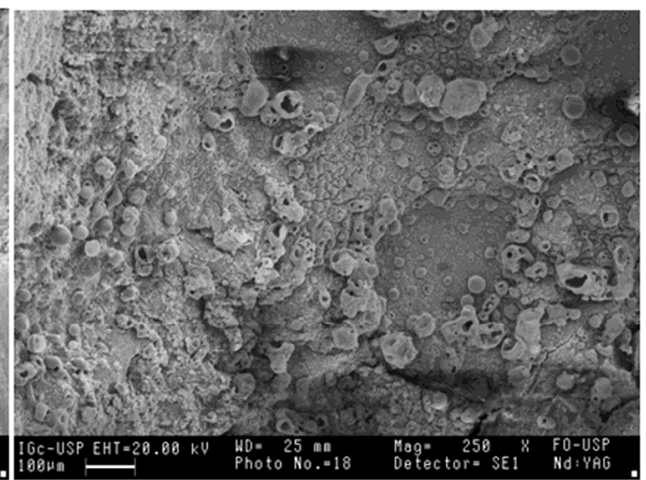

B

Fig. 6. Scanning electron micrographs of sound (A) and carious (B) human dentin after irradiation with a Nd:YAG laser $(\lambda=1064 \mathrm{~nm}$, pulse width of $100 \mu \mathrm{s}$, repetition rate of 20 $\mathrm{Hz}$, beam diameter of $300 \mu \mathrm{s})$. A - When sound dentin is irradiated by Nd:YAG laser melting and carbonization can be detected covering all the irradiated area, no dentinal tubules can be observed; B - Carious Nd:YAG irradiated dentin also presents melting and carbonization areas, very similar to the sound irradiated dentine. Original magnification: $250 \mathrm{X}$.

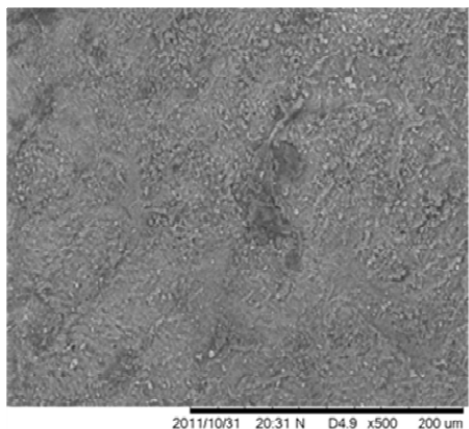

A

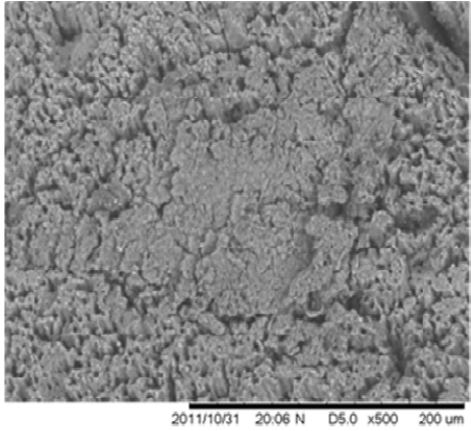

C

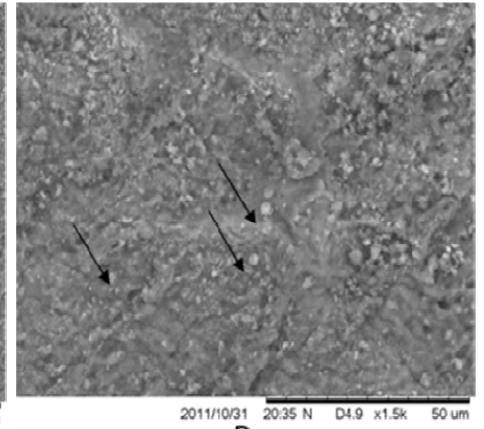

B

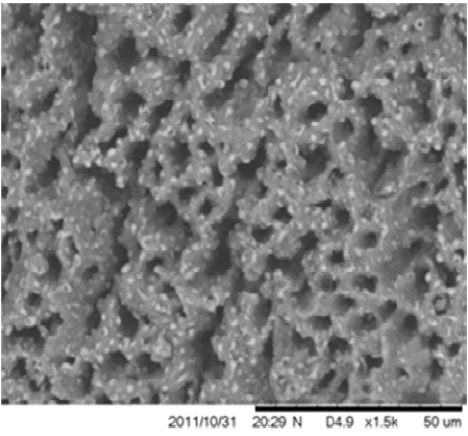

D

Fig. 7. Scanning electron micrographs of sound and carious human dentin after irradiation with a Nd:YAG $(\lambda=1064 \mathrm{~nm})$, operating at pulse width of $5 \mathrm{~ns}$, beam diameter of $900 \mu \mathrm{m}$, 
repetition rate of $20 \mathrm{~Hz}$, scanning speed of $2 \mathrm{~mm} / \mathrm{s}$, energy per pulse of $280 \mathrm{~mJ}$ and energy density of $0.44 \mathrm{~J} / \mathrm{cm}^{2}$. During irradiations, the samples were positioned and moved with a linear translation stage with $10 \mu \mathrm{m}$ resolution, and it was performed 10 scans. In A, after irradiation on sound dentin, it is possible to evidence fully occlusion of dentinal tubules. In $\mathrm{B}$, a higher magnification of image $\mathrm{A}$, the presence of fine globules and glazed areas (arrows), typical of melting and recrystallization of tissue can be detected. It is not observed the presence of smear layer or any signal of carbonization and cracks. In $C$ a representative image of carious dentin after irradiation is showed, and the presence of an irregular tissue, with some projections of dentinal tubules and absence of biofilm and smear layer is evidenced. It is not observed thermal damages such as cracks or carbonization of tissue. Some areas present dentinal tubules completely opened, while other areas present closed dentinal tubules. In $\mathrm{D}$, a higher magnification of image $\mathrm{C}$, dentinal tubules are completely opened and the presence of small globules on intertubular tissue (arrows), typical of melting and recrystalization are observed. Original magnification: A and C $=500 \mathrm{X} ; \mathrm{B}$ and $\mathrm{D}=1500 \mathrm{X}$.

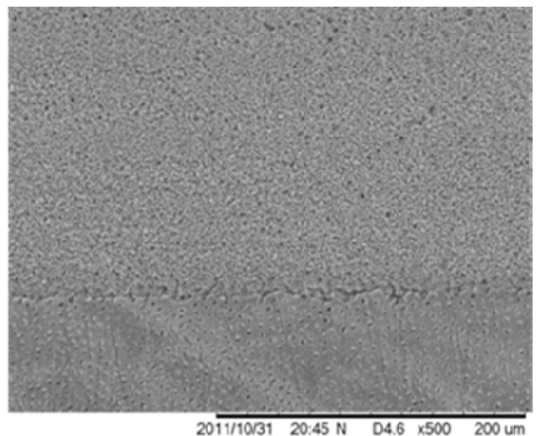

A

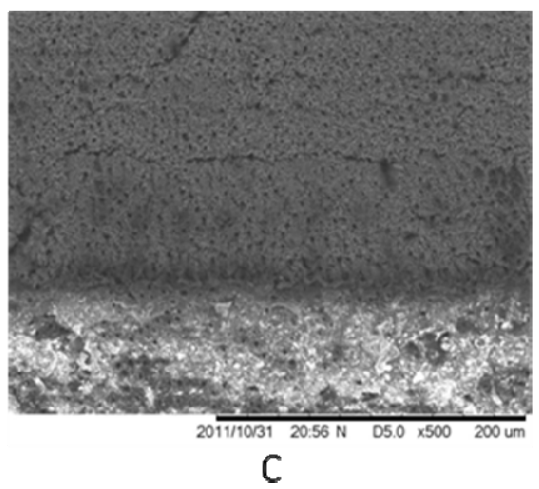

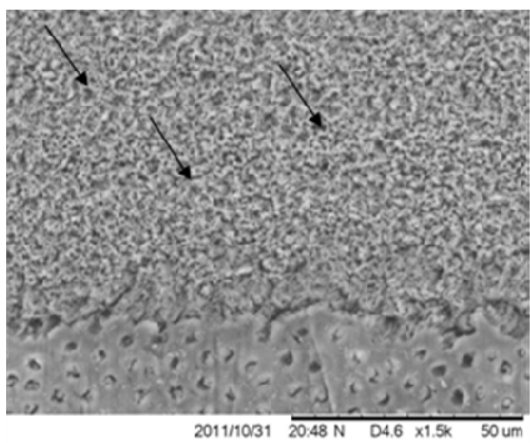

B

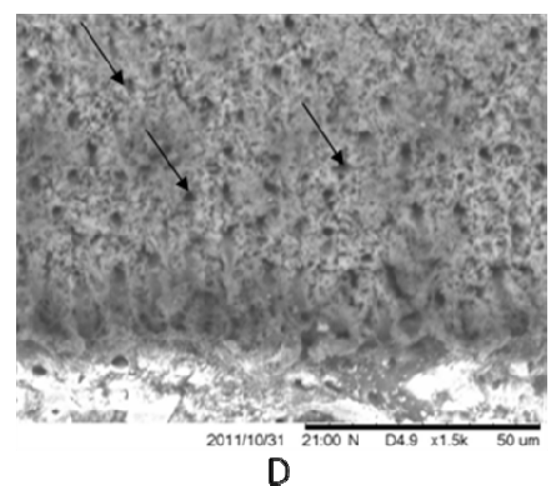

Fig. 8. Scanning electron micrographs of sound ( $\mathrm{A}$ and $\mathrm{B})$ and carious ( $\mathrm{C}$ and $\mathrm{D})$ human dentin after irradiation with a Ti:sapphire laser $\left(\mathrm{Ti}_{\mathrm{Al}} \mathrm{Al}_{2} \mathrm{O}_{3}, \lambda=830 \mathrm{~nm}\right)$, operating at pulse width of $40 \mathrm{fs}$ (FWHM), beam diameter of $20 \mu \mathrm{m}$, repetition rate of $100 \mathrm{~Hz}$, scanning speed of $5 \mathrm{~mm} / \mathrm{s}$ and energy per pulse of $104 \mathrm{~mJ}$. During irradiations, the samples were positioned and moved with a linear translation stage with $10 \mu \mathrm{m}$ resolution, and it was performed 10 scans. In A, it is possible to evidence the ablation of sound dentin (upper), with a regular 
edge with non irradiated dentin (bottom). It is observed a clear and uniform ablation, with absence of cracks, melting or carbonization. As well, it is not observed the presence of projections or conical craters, indicating that the laser interaction with sound dentin is not influenced by the composition or the presence of dentinal tubules. In B, it is showed a higher magnification of the same image, evidencing the ablation of sound dentin (upper), in contrast with non irradiated dentin (bottom). It is also noted the presence of opened dentinal tubules (arrows), and absence of smear layer. In C, it is observed a clear and uniform ablation of carious dentin, with the creation of a regular ablated surface and absence of cracks, melting or carbonization. In D, it is showed a higher magnification of image $C$, showing that the biofilm was removed and it was exposed the openings of dentinal tubules (arrows). It is also observed the higher depth and the precise edge of ablated area, indicating that it was removed a higher amount of carious tissue when compared to sound dentin irradiation. Original magnification: $\mathrm{A}$ and $\mathrm{C}=500 \mathrm{X}$; B and $\mathrm{D}=1500 \mathrm{X}$.

Based on the figures presented above, we can conclude that it is fundamental to investigate bond strength to irradiated caries-affected dentine, which is a clinically relevant tissue, as lasers are a contemporaneous tool in daily clinical practice. In this way, it is obvious that the performance of the adhesive systems is different when applied in irradiated dentin. To obtain a long lasting clinical result, specific adhesive systems should be developed to be used in irradiated dental surfaces, especially in caries-affected dentine.

Methods of inducing artificial caries lesions have been used to standardize the decayed substrate for laboratory testing. Cariology studies using artificial caries lesions have been performed to assess preventive effect of fluoride agents, test methods of caries removal and adhesion on caries affected dentine.

Some in vitro caries models have been reported. In the chemical method, the acidified gel technique and $\mathrm{pH}$-cycling method are included; in contrast, microorganism strains with known cariogenicity are used in the microbiological method in a way whereby the acid from bacterial metabolism demineralizes the dental structure (Steiner-Oliveira et al., 2011). More elaborate systems involving chemostats, flowcells, artificial mouths, and constant-depth film fermenter have been developed in an attempt to better mimic the environment of the oral cavity. However, their high cost and complex apparatus requirements are often limiting factors (Gilmour et al., 1990).

Some authors believe that the bacterial model is the closest to the conditions found in vivo (Gilmour et al., 1990). The steps of an example of a microbiological method are described, as follows. Initially, the dental specimens need to be sterilized with gamma ray irradiation (25 KGy) since the teeth should be free of microorganisms. A microorganism strain with known cariogenicity, for example, Streptococcus mutans ATCC 25175 or UA159 must be incubated in Tryptic Soy Broth (TSB) media supplemented with 5\% sucrose to obtain bacterial growth. After growth, the colonies will be transferred into tubes containing TSB (with 5\% sucrose) to initiate microorganism preconditioning. The dental specimen should be immersed in a solution (TSB with 5\% sucrose and a quantity of the inoculums broth) and will be maintained therein for at least 7 days, being transferred to a fresh solution every $24 \mathrm{~h}$. During the incubation periods, tests should be performed to check for the presence of bacterial contaminants with the use of a solid culture medium (Tryptic Soy Agar TSA)(Azevedo et al., 2011). 
Caries-affected substrate obtained in vitro by the microbiological method significantly contributes to the field of adhesion, because it will allow laboratory tests to be performed on standard caries-affected dentine, which is a clinically relevant substrate. The microbiological method allows the production of artificial caries-affected dentine effectively induced for 7 days and demineralization depth is standardized and it is confirmed by optical coherence tomography (OCT) (Azevedo et al., 2011). Efforts have been made to produce artificial caries-affected dentine and bond strength studies must be conducted, especially in laser irradiated tissues, to associate the use of laser to remove caries and long lasting clinical treatments.

\section{Conclusion}

This chapter presented laser technology as an alternative to caries removal, attending the conservative principals of dentistry, assuring that minimally invasive procedures can be used to treat caries lesions.

\section{Acknowledgement}

The authors would like to thank to Dr. Wagner de Rossi, Dr. Marcus Paulo Raele, Prof Moises O. Santos, Leandro Matiolli Machado and Prof. Carolina Benetti for their kind assistance during irradiations; and also to Prof. Dr. Alessandra Pereira de Andrade for her assistance with figures management. Authors also wish to thank FAPESP (\#2010/10126-3) for partially supporting the project of writing this book chapter.

\section{References}

Altshuler, G.B., Belikov, A.V. \& Erofeev, A.V. (1994). Laser treatment of enamel and dentin by different er-lasers. Proceedings of SPIE, Vol. 2128, pp. 273-281, Los Angeles, CA, Jan 1994.

Ana, P.A., Bachmann, L. \& Zezell, D.M. (2006) Lasers effects on enamel for caries prevention. Laser Physics, Vol.16, No.5, pp. 865-75.

Ana, P.A., Blay, A., Miyakawa, W. \& Zezell, D.M. (2007) Thermal analysis of teeth irradiated with Er,Cr:YSGG at low fluences. Laser Physics Letters, Vol.4, No.11, pp.827-834.

Antunes, A., de Rossi, W. \& Zezell, D.M. (2006) Spectroscopic alterations on enamel and dentin after nanosecond Nd:YAG laser irradiation. Spectrochim Acta A Mol Biomol Spectroscopy, Vol.64, No.5, pp.1142-6.

Antunes, A., Vianna, S.S., Gomes, A.S.L., de Rossi, W. \& Zezell, D.M. (2005). Surface morphology, elemental distribution, and spectroscopic changes subsequent the application of nanosecond pulsed Nd:YAG laser on dental enamel surface. Laser Physics Letters, Vol.2, No.3, pp.141-147.

Apel. C., Meister, J., Gotz, H., Duschner, H. \& Gutknecht, N. (2005). Structural changes in human dental enamel after subablative erbium laser irradiation and its potential use for caries prevention. Caries Research, Vol.39, pp. 65-70. 
Azevedo, C.S., Trung, L.C.E., Simionato, M.R.L., Freitas, A.Z.F. \& Matos, A.B. (2011). Evaluation of caries-affected dentin with optical coherence tomography. Brazilian Oral Research. Vol. 25, No.5, pp.407-13.

Bachmann, L., Craievich, A.F. \& Zezell, D.M. (2004). Crystalline structure of dental enamel after Ho:YLF laser irradiation. Archives of Oral Biology, Vol.49, No.11, pp.923-9.

Bachmann, L., Rosa, K.,, Ana, P.A., Zezell, D.M., Craievich, A.F. \& Kellermann, G. (2009). Crystalline structure of human enamel irradiatedwith Er,Cr:YSGG laser. Laser Physics Letters, Vol.6, No.2, pp.159-162.

Benedicenti, S., Cassanelli, C., Signore, A, Ravera, G. \& Angiero, F. (2008) Decontamination of root canals with the gallium-aluminum-arsenide laser: an in vitro study. Photomedicine and Laser Surgery, Vol.26, No.4, pp.367-70.

Boari, H.G.D., Ana, P.A., Eduardo, C.P., Powell, G.L. \& Zezell, D.M. (2009). Absorption and thermal study of dental enamel when irradiated with Nd:YAG laser with the aim of caries prevention. Laser Physics, Vol.19, No.7, pp.1463-1469.

Botta, S.B., Ana, P.A., de Sa Teixeira, F., da Silveira Salvadori, M.C. \& Matos, A.B. (2011) Relationship between surface topography and energy density distribution of Er,Cr:YSGG beam on irradiated dentin: an atomic force microscopy study. Photomedicine and Laser Surgery, Vol.29, No.4, pp.261-9.

Botta, S.B., Ana, P.A., Zezell, D.M., Powers, J.M. \& Matos, A.B. (2009) Adhesion after erbium, chromium:yttrium-scandium-gallium-garnet laser application at three different irradiation conditions. Lasers in Medical Science, Vol.24, No.1, pp.67-73.

Botta, S.B., Vieira, S.N., Cordon, R., Marques, M.M. \& Matos, A.B. (2009) Can the method of primer application influence adhesion to Er:YAG-laser irradiated dentin? Journal of Contemporary Dental Practice. Vol.10, No.1, pp.49-57.

De Moor, R.J. \& Delme, K.I. (2010). Laser-assisted cavity preparation and adhesion to erbium-lased tooth structure: part 2. present-day adhesion to erbium-lased tooth structure in permanent teeth. Journal of Adhesive Dentistry, Vol.12, No.2, pp.91-102.

Dommisch, H., Peus, K., Kneist, S., Krause, F., Braun, A., Hedderich, J., Jepsen, S. \& Eberhard, J. (2008) Fluorescence-controlled Er:YAG laser for caries removal in permanent teeth: a randomized clinical trial. European Journal of Oral Science, Vol.116, No.2, pp.170-6.

Dundar, B. \& Guzel, K.G. (2011) An analysis of the shear strength of the bond between enamel and porcelain laminate veneers with different etching systems: acid and Er,Cr:YSGG laser separately and combined. Lasers in Medical Science. Vol.26, No.6, pp.777-82.

Eberhard, J., Bode, K., Hedderich, J. \& Jepsen, S. (2008) Cavity size difference after caries removal by a fluorescence-controlled Er:YAG laser and by conventional bur treatment. Clinical Oral Investigations. Vol.12, No.4, pp.311-8.

Eberhard, J., Eisenbeiss, A.K., Braun, A., Hedderich, J. \& Jepsen, S. (2005) Evaluation of selective caries removal by a fluorescence feedback-controlled Er:YAG laser in vitro. Caries Research. Vol.39, No.6, pp.496-504. 
Featherstone, J.D.B. (2000) The science and practice of caries prevention. Journal of the American Dental Association. 131(7): 887-899.

Freitas, A.Z., Freschi, L.R., Samad, R.E., Zezell, D.M., Gouw-Soares, S.C. \& Vieira ND. (2010) Determination of ablation threshold for composite resins and amalgam irradiated with femtosecond laser pulses. Laser Physics Letters. Vol. 7, No.3, pp.236-241.

Fried, D. (2000) IR laser ablation of dental enamel. Lasers in dentistry VI. Proceedings of SPIE, Vol. 1, No.4, pp. 136-148, San Jose, CA, Jan 2000.

Fried, D., Ashouri, N., Breunig, T. \& Shori, R. (2002) Mechanism of water augmentation during IR laser ablation of dental enamel. Lasers in Surgery and Medicine. Vol.31, No.3, pp.186-93.

Fried, D., Featherstone, J.D.B., Visuri, S.R., Seka, W. \& Walsh, J.T. The caries inhibition potential of Er:YAG and Er:YSGG laser radiation. Lasers in dentistry II, Proceedings of SPIE, Vol. 2672, pp.73-78, San Jose, CA, Jan 1996.

Gilmour, A.S.M, Edmunds, D.G. \& Dummer, P.M.H. (1990) The production of secondary caries-like lesions on cavity walls and the assessment of microleakage using an in vitro microbial caries system. Journal of Oral Rehabilitation. Vol.17, No.6, p.573-8.

Gwinnett, AJ. (1992) Structure and composition of enamel. Operative Dentistry. Vol. 5, pp. 1017.

Hibst, R. \& Keller, U. (1989) Experimental studies of the application of the Er:YAG laser on dental hard substances: I. Measurement of the ablation rate. Lasers in Surgery and Medicine. Vol.9, No.4, pp.338-44.

Jepsen, S., Açil, Y., Peschel, T., Kargas, K. \& Eberhard, J. (2008) Biochemical and morphological analysis of dentin following selective caries removal with a fluorescence-controlled Er:YAG laser. Lasers in Surgery and Medicine. Vol.40, No.5, pp.350-7.

Kamata, M., Imahoko, T., Ozono, K. \& Obara, M. (2004). Materials processing by use of a Ti : Sapphire laser with automatically-adjustable pulse duration. Applied Physics AMaterials Science \& Processing. Vol. 79, No. 7, pp.1679-1685.

Koba, K., Kimura, Y., Matsumoto, K., Takeuchi, T., Ikarugi, T. \& Shimizu, T. (1998) A histopathological study of the morphological changes at the apical seat and in the periapical region after irradiation with a pulsed $\mathrm{Nd}$ :YAG laser. International Endodontic Journal. Vol.31, No.6, pp.415-20.

Kornblit, R., Trapani, D., Bossù, M., Muller-Bolla, M., Rocca, J.P. \& Polimeni, A. (2008) The use of Erbium:YAG laser for caries removal in paediatric patients following Minimally Invasive Dentistry concepts. European Journal of Paediatric Dentistry. Vol.9, No.2, pp.81-7.

Krause, F., Braun, A., Lotz, G., Kneist, S., Jepsen, S. \& Eberhard, J. (2008). Evaluation of selective caries removal in deciduous teeth by a fluorescence feedbackcontrolled Er:YAG laser in vivo. Clinical Oral Investigations. Vol. 12, No.3, pp.209-15.

Kruger, J., Kautek, W. \& Newesely, H. (1999). Femtosecond-pulse laser ablation of dental hydroxyapatite and single-crystalline fluoroapatite. Applied physics A-material science procedure. Vol.69, pp.S403-S407. 
Kunawarote, S., Nakajima, M., Foxton, R.M. \& Tagami, J. (2011) Effect of pretreatment with mildly acidic hypochlorous acid on adhesion to caries-affected dentin using a selfetch adhesive. European Journal of Oral Science. Vol. 119, pp.86-92.

Lang-Bicudo, L., Eduardo, F.P., Eduardo, C.P. \& Zezell, D.M. (2008) LED phototherapy to prevent mucositis: a case report. Photomedicine and Laser Surgery. Vol.26, No.6, pp.609-13.

Lizarelli, R.F.Z., Costa, M.M., Carvalho-Filho, E., Nunes, F.D. \& Bagnato, V.S. (2008). Selective ablation of dental enamel and dentin using femtosecond laser pulses. Laser Physics Letters, Vol. 5, No.1, pp.63-69.

Marquezan, M., Corrêa, F.N.P., Sanabe, M.E., Filho, L.E.R., Hebling, J. \& Guedes Pinto A.C. (2009) Artificial methods of dentine caries induction: A hardness and morphological comparative study. Archives of Oral Biology. Vol.54, No.12, pp.1111-7.

McDonald, A., Claffey, N., Pearson, G., Blau, W. \& Setchell, D. (2001). The effect of Nd:YAG pulse duration on dentine crater depth. Journal of Dentistry. Vol.29, No.1, pp.43-53.

Mobarak, E.H., El-Korashy, D.I. \& Pashley, D.H. (2010). Effect of Chlorhexidine concentrations on micro-shear bond strength of self-etch adhesive to normal and caries-affected dentin. American Journal of Dentistry. Vol.23, No.4, pp.217-222.

Moldes, V.L., Capp, C.I., Navarro, R.S., Matos, A.B., Youssef, M.N. \& Cassoni, A. (2009) In vitro microleakage of composite restorations prepared by Er:YAG/Er,Cr:YSGG lasers and conventional drills associated with two adhesive systems. Journal of Adhesive Dentistry, Vol. 11, No.3, pp.221-229.

Moretto, S.G., Azambuja Jr., N., Arana-Chavez, V.E., Reis, A.F., Giannini, M., Eduardo C.P. \& De Freitas, P.M. (2011). Effects of ultramorphological changes on adhesion to lased dentin-Scanning electron microscopy and transmission electron microscopy analysis. Microscopy Research and Technique. Vol.74, No.8, pp.720-6.

Nammour, S., Rocca, J.P., Pireaux, J.J., Powell, G.L., Morciaux, Y. \& Demortier, G. (2005) Increase of enamel fluoride retention by low fluence argon laser beam: a 6month follow-up study in vivo. Lasers in Surgery and Medicine. Vol.36, No.3, pp.220-4.

Nammour, S., Zeinoun, T., Bogaerts, I., Lamy, M., Geerts, S.O., Bou Saba, S., Lamard, L., Peremans, A. \& Limme, M. (2010). Evaluation of dental pulp temperature rise during photo-activated decontamination (PAD) of caries: an in vitro study. Lasers in Medical Science. Vol.25, No.5, pp.651-4.

Navarro, R.S., Gouw-Soares, S., Cassoni, A., Haypek, P., Zezell, D.M. \& Eduardo, C.P. (2010). The influence of erbium:yttrium-aluminum-garnet laser ablation with variable pulse width on morphology and microleakage of composite restorations. Lasers in Medical Science. Vol.25, No.6, pp.881-9.

Neev, J., Da Silva, L.B., Feit, M.D., Perry, M.D., Rubenchik, A.M. \& Stuart, B.C. (1996) Ultrashort pulse lasers for hard tissue ablation. Eee Journal of Selected Topics in Quantum Electronics. Vol.2., No.4, pp. 790-800. 
Neves, A.A., Coutinho, E., De Munck, J. \& Van Meerbeek B. (2010). Caries-removal effectiveness and minimal-invasiveness potential of caries-excavation techniques: a micro-CT investigation. Journal of Dentistry. Vol.39, No.2, pp.154-62.

Niemz M.H. (1995). Cavity preparation with the Nd:YLF picosecond laser. Journal of Dental Research. Vol.74, No.5, pp.1194-9.

Niemz, M.H. (2004). Laser-tissue interactions - fundamentals and applications. SpringerVerlang, ISBN 3-540-40553-4, Leipzig, Germany.

Obeidi, A., McCracken, M.S., Liu, P.R., Litaker, M.S., Beck, P. \& Rahemtulla, F. (2009) Enhancement of bonding to enamel and dentin prepared by Er,Cr:YSGG laser. Lasers Surgery and Medicine. Vol.41, No.6, p.454-62.

Olivi, G., Angiero, F., Benedicenti, S., Iaria, G., Signore, A. \& Kaitsas, V. (2010) Use of the erbium, chromium:yttrium-scandium-gallium-garnet laser on human enamel tissues. Influence of the air-water spray on the laser-tissue interaction: scanning electron microscope evaluations. Lasers in Medical Science. Vol.25, No.6, pp.793-7.

Perdigão, J. (2010). Dentin bonding-Variables related to the clinical situation and the substrate treatment. Dental Materials. Vol. 26, No.2, pp.e24-e37.

Perry, M.D., Stuart, B.C., Banks, P.S., Feit, M.D., Yanovsky, V. \& Rubenchik, A. M. (1999) Ultrashort-pulse laser machining of dielectric materials. Journal of Applied Physics. Vol.85, No.9, pp.6803-10.

Pike, P., Parigger, C., Splinter, R. \& Lockhart, P. (2007). Temperature distribution in dental tissue after interaction with femtosecond laser pulses. Applied Optics. Vol.46, No.34, pp.8374-8378.

Rechmann, P., Fried, D., Le, C.Q., Nelson, G., Rapozo-Hilo, M., Rechmann, B.M. \& Featherstone, J.D. (2011). Caries inhibition in vital teeth using 9.6- $\mu \mathrm{m} \mathrm{CO}_{2}$-laser irradiation. Journal of Biomedical Optics. Vol.16, No.7, pp.071405.

Schelle, F., Engelbach, C., Brede, O., Braun, A., Frentzen, M. (2011). Ablation of caries using an ultra short pulsed laser system. Journal of Dental Research. Vol. 90, Spec Issue B: abstract 722 .

Seka, W., Featherstone, J.D.B., Fried, D., Visuri, S.R. \& Walsh JT. (1996) Laser ablation of dental hard tissue: From explosive ablation to plasma-mediated ablation. Lasers in Dentistry, Proceedings of SPIE, Vol. 2672, pp. 144-158, Los Angeles, CA, Jan 1996.

Seka,W., Fried, D., Featherstone, JDB. (1995). Light deposition in dental hard tissue and simulated thermal response. Journal of Dental Research. Vol.74, pp.1086-92.

Serbin, J., Bauer, T., Fallnich, C., Kasenbacher, A. \& Arnold, W.H. (2002). Femtosecond lasers as novel tool in dental surgery. Applied Surface Science. Vol.197, pp. 737-740.

Sperandio, F.F., Meneguzzo, D.T., Ferreira, L.S., Ana, P.A., Azevedo, L.H. \& Sousa, S.C. (2011) Different air-water spray regulations affect the healing of Er,Cr:YSGG laser incisions. Lasers in Medical Science. Vol.26, No.2, pp.257-65.

Steiner-Oliveira, C., Rodrigues, L.K.A., Zanin, I.C.J., de Carvalho, C.L., Kamiya, R.U., Hara, A.T. et al. (2011). An in vitro microbial model associated with sucrose to produce dentin caries lesions. Cent European Journal Biology. Vol. 6, No.3, pp.414:21. 
Stern, R.H. \& Sognnaes, R.F. (1964). Laser beam effect on dental hard tissue. Journal of Dental Research. Vol. 43, No.5, pp. 873.

Stern, D., Puliafito, C.A., Dobi, E.T., Reidy, W.T. (1989). Corneal ablation by nanosecond, picosecond and femtosecond lasers at $532 \mathrm{~nm}$ and $625 \mathrm{~nm}$. Archives of Ophthalmology. Vol.107, pp.587- 592.

Stock, M., Hibst, R. \& Keller, U. (1997). Comparison of Er:YAG and Er:YSGG laser ablation of dental hard tissues. Proceedings of SPIE. Vol. 3192, pp. 88-95, Los Angeles, CA, Jan 1997.

Strassl, M., Wieger, V., Brodoceanu, D., Beer, F., Moritz, A. \& Wintner, E. (2008). Ultra-Short Pulse Laser Ablation of Biological Hard Tissue and Biocompatibles. Journal of Laser Micro Nanoengineering. Vol.3, No.1, pp.30-40.

Strickland, P. \& Mourou, G. (1985) Compression of amplified chirped optical pulses. Optics Community. Vol. 56, pp. 219.

Tachibana, A., Marques, M.M., Soler, J.M. \& Matos, A.B. (2008). Erbium, chromium:yttrium scandium gallium garnet laser for caries removal: influence on bonding of a selfetching adhesive system. Lasers in Medical Science. Vol.23, No.4, pp.435-41.

White, J.M., Goodis, H.E., Hennings, D., Ho, W. \& Hipona, C.T. (1994). Dentin ablation rate using Nd:YAG and Er:YAG lasers. Journal of Dental Research. Vol. 73, abs 1733, pp.318.

White, J.M., Goodis, H.E., Setcos, J.C., Eakle, S., Hulscher, B.E. \& Rose, C.L. (1993). Effects of pulsed Nd:YAG laser energy on human teeth: a three-year follow-up study. Journal of the American Dental Association. Vol.124, No.7, pp.45-51.

Wieger, V., Strassl, M. \& Wintner, E. (2006). Pico- and microsecond laser ablation of dental restorative materials. Laser and Particle Beams. Vol. 24, pp.41-45.

Yamada, Y., Hossain, M., Nakamura, Y., Suzuki, N. \& Matsumoto, K. (2001). Comparison between the removal effect of mechanical, Nd:YAG, and Er:YAG laser systems in carious dentin. Journal of Clinical Laser Medicine Surgery. Vol.19, No.5, pp.239-43.

Yazici, A.R., Baseren, M. \&, Gorucu, J. (2010). Clinical comparison of bur- and laserprepared minimally invasive occlusal resin composite restorations: two-year follow-up. Operative Dentistry. Vol.35, No.5, pp.500-7.

Yilmaz, H.G., Kurtulmus-Yilmaz, S., Cengiz, E., Bayindir, H. \& Aykac, Y. (2011).Clinical evaluation of Er,Cr:YSGG and GaAlAs laser therapy for treating dentine hypersensitivity: A randomized controlled clinical trial. Journal of Dentistry. Vol.39, No.3, pp.249-54.

Zanchi, C.H., Lund, R.G., Perrone, L.R., Ribeiro, G.A., Del Pino, F.A.B., Pinto, M.B. \& Demarco FF. (2011). Microtensile bond strength of two-step etch-and-rinse adhesive systems on sound and artificial caries-affected dentin. American Journal of Dentistry. Vol. 23, No.3, pp.152-6.

Zawaideh, F., Palamara, J.E.A., Messer, L.B. (2011). Bonding of resin composite to cariesaffected dentin after Carisolv ${ }^{\circledR}$ treatment. Pediatric Dentistry. Vol. 33, No.3, pp.213220.

Zezell, D.M., Boari, H.G., Ana, P.A., Eduardo, C.P. \& Powell, GL. (2009) Nd:YAG laser in caries prevention: a clinical trial. Lasers Surgery and Medicine. Vol.41, No.1, pp.31-5. 
Zijp, J.R. \& Bosch, J.J. (1993). Theoretical model for the scattering of light by dentin and comparison with measurements. Applied Optics. Vol.32, No.4, pp.411-5. 


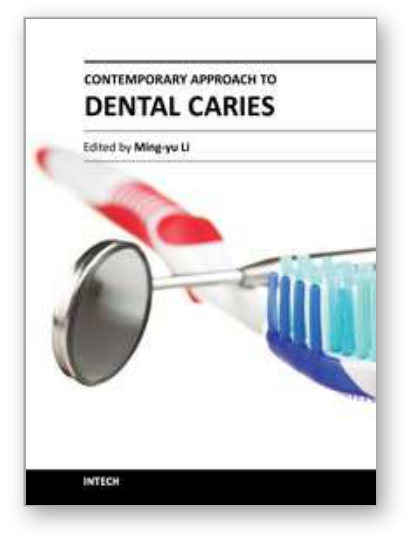

\author{
Contemporary Approach to Dental Caries \\ Edited by Dr. Ming-Yu Li
}

ISBN 978-953-51-0305-9

Hard cover, 488 pages

Publisher InTech

Published online 14, March, 2012

Published in print edition March, 2012

With an update of the recent progress in etiology, pathogenesis, diagnosis, and treatment of caries, it may be said that the final defeat of dental caries is becoming possible soon. Based on the research in this area in recent decades, "Contemporary Approach to Dental Caries" contained the caries in general, the diagnosis of caries, caries control and prevention, the medical treatment of caries, dental caries in children and others such as secondary caries. This book provides the reader with a guide of progress on the study of dental caries. The book will appeal to dental students, educators, hygienists, therapists and dentists who wish to update their knowledge. It will make you feel reading is profitable and useful for your practice.

\title{
How to reference
}

In order to correctly reference this scholarly work, feel free to copy and paste the following:

Adriana Bona Matos, Cynthia Soares de Azevedo, Patrícia Aparecida da Ana, Sergio Brossi Botta and Denise Maria Zezell (2012). Laser Technology for Caries Removal, Contemporary Approach to Dental Caries, Dr. Ming-Yu Li (Ed.), ISBN: 978-953-51-0305-9, InTech, Available from:

http://www.intechopen.com/books/contemporary-approach-to-dental-caries/laser-technology-for-cariesremoval

\section{INTECH}

open science | open minds

\section{InTech Europe}

University Campus STeP Ri

Slavka Krautzeka 83/A

51000 Rijeka, Croatia

Phone: +385 (51) 770447

Fax: +385 (51) 686166

www.intechopen.com

\section{InTech China}

Unit 405, Office Block, Hotel Equatorial Shanghai

No.65, Yan An Road (West), Shanghai, 200040, China

中国上海市延安西路65号上海国际贵都大饭店办公楼 405 单元

Phone: +86-21-62489820

Fax: +86-21-62489821 
(C) 2012 The Author(s). Licensee IntechOpen. This is an open access article distributed under the terms of the Creative Commons Attribution 3.0 License, which permits unrestricted use, distribution, and reproduction in any medium, provided the original work is properly cited. 